\title{
KEUTUHAN NADA DAN MAKNA DALAM SUSUNAN BAHASA AL-QURAN
}

\author{
Dedy Wahyudin, Djuaini \\ Magister PBA Pascasarjana UIN Mataram, PIAUD FTK UIN Mataram \\ dewasa2018@uinmataram.ac.id, hajibeliau@gmail.com
}

\begin{abstract}
This article aimed to describe three focuses: first, how sounds of language signify its meaning; second, how composition of sounds corresponds to the composition of meaning; and third, what are the proofs that the sounds of al-Qur'an verses compose its meanings. Research approach of this article is qualitative approach using library research. Based on phonological and semantic studies, this research concludes that the relation between words and its meaning in Arabic is natural relation; sounds of al-Qur'an therefore indicates its meaning; and it can be proofed by analysing al-Qur'an from phonological and semantic perspective.
\end{abstract}

Keywords: Al-Qur'an, Sound, Meaning, Arabic Language

\begin{abstract}
Abstrak: Artikel ini bertujuan untuk menggambarkan tiga fokus masalah sekaligus: pertama, bagaimana bunyi bahasa menunjukkan maknanya; kedua, bagaimana susunan bunyi bahasa berkorespondensi dengan maknanya; dan ketiga, apakah bukti bahwa bunyi al-Qur'an mengindikasikan maknannya. Pendekatan yang dipakai dalam tulisan ini adalah pendekatan kualitatif dengan jenis penelitian pustaka. Sumber data berasal dari kajian para linguis dan ahli tafsir untuk selanjutnya dianalisis dan dikonstruksi untuk menjawab permasalahan yang telah ditentukan.Dengan menggunakan kajian fonologi dan semantik, penelitian ini sampai pada kesimpulan bahwa hubungan kata dan makna dalam bahasa Arab bersifat natural ('alāqah țabi'iyyah); dengan demikian, bunyi al-Qur'an menunjukkan -atau mengarahkan para pembaca kepada-- maknanya; dan hal ini dapat dibuktikan dengan manganalisis ayatayat al-Qur'an dengan menggunakan perspektif fonologi dan semantik.
\end{abstract}

Kata Kunci: Al-Qur'an, Bunyi, Makna, Bahasa Arab

\section{A. Pendahuluan}

Al-Qur'an adalah mukjizat terbesar sepanjang masa. Ia tidak terbatas ruang dan waktu. Perkembangan ilmu pengetahuan dari masa ke masa memperkuat kemukjizatannya. Dikaji dari aspek apapun, al-Qur'an tetaplah mukjizat. Dari aspek aturan, hukum-hukum al-Qur'an selalu menjamin kemasalahatan manusia kapapanpun dan dimanapun. Dari aspek sains, al-Qur'an adalah kitab terbuka 
yang selalu benar dan dibuktikan kebenarannya oleh setiap perkembangan ilmu pengetahuan. Dari aspek kebenaran informasi, sejarah membuktikan bahwa apapun informasi al-Qur'an tentang peristiwa yang belum terjadi selalu dibuktikan tepat setelah peristiwa itu terjadi. Dari aspek bahasa, al-Qur'an seperti bangunan utuh yang tidak mengalami kontradiksi internal satu hurufpun. Semua berada di tempat yang tepat merangkai kesempurnaan bahasa al-Qur'an. Kesempurnaan bahasa yang berada di luar kemampuan manusia, betapapun kecanggihannya dalam menyusun huruf, kata dan kalimat.

Jika susunan (nazm) bahasa al-Qur'an -sebagaimana diyakinkan oleh Abd alQāhir al-Jurjānī--adalah rahasia kemukjizatan al-Qur'an sebelum yang lain-lain, maka susunan itu pastilah terdiri dari huruf, kata, kalimat, dan narasi yang membentuk satu kesatuan utuh ayat-ayat al-Qur'an, dari awal sampai akhir. Jika huruf, sebagaimana diintrodusir Abu Nașr al-Farabi, Ibnu Sina dll adalah suara tanpa bunyi maka suara adalah unsur pembentuk pertama kemukjizatan al-Qur'an itu; bukan sekedar suara tetapi suara yang bernada; bukan sekedar nada tetapi nada yang berkorespondensi dengan makna. Jika aspek kata (morfologis) dan kalimat (sintaksis) telah banyak dielaborasi oleh para ulama, baik ulama bahasa (lugawiyyūn) atau ulama tafsir (mufassirūn) maka aspek nada yang merangkai makna belum banyak didedahkan oleh para ulama. Oleh karena itu, tulisan ini adalah upaya untuk meneropong korespondensi nada dan makna yang membentuk keutuhan bahasa al-Qur'an.

Elaborasinya dimulai dari fakta bahwa al-Qur'an adalah suara sebelum tulisan; ia turun berbentuk suara (nazala nuzūlan șautiyyan) sebelum dilambangkan dalam bentuk tulisan. Karena suara adalah dasar turunnya al-Qur'an maka sudah pasti suara menunjuk makna. Susunan suara yang terbentuk dalam fonem, kemudian morfem, struktur dan teks mengindikasikan makna yang selanjutnya dibentuk oleh susunan kata dan kalimat. Dengan demikian, fokus tulisan ini adalah: 1) bagaimana suara atau nada menunjuk makna?;2) bagaimana aliran suara berkorespondensi dengan aliran makna?;3) apa saja contoh-contoh ayat-ayat al-Qur'an yang menegaskan korespendensi itu?. Perangkat ilmunya adalah gabungan ilmu fonetik dan semantik. Kajiannya menjadi fonetis-semantis. Harapannya, tulisan ini berhasil membuktikan bahwa pilihan huruf yang melahirkan bunyi dalam al-Qur'an adalah pilihan by design sebagai akar pertama rahasia kemukjizatan al-Qur'an untuk selanjutnya diteruskan oleh susunan kata, kalimat dan teks. Pembuktian asumsi tulisan ini tidak fokus-detil pada satu ayat atau surat tertentu dalam al-Qur'an, tetapi secara terukur berselancar untuk menampilkan contoh-contoh ayat atau potongan ayat al-Qur'an yang membuktikan betapa bunyi al-Qur'an berimplikasi dalam satu kesatuan yang harmonis dengan makna yang hendak ditunaikan.

\section{B. Landasan Teori}

Wilayah kerja tema tulisan ini berada tiga bidang yang saling kait mengkait: susunan bahasa al-Qur'an,suara bahasa, dan hubungan suara dan makna dalam ayatayat al-Qur'an. Untuk menjelaskan susunan bahasa al-Qur'an, penulis merujuk ke 
teori nażm yang terutama diidentikkan dengan Abd al-Qāhir al-Jurjānï. Teori nażm menjelaskan rahasia kemukjizatan al-Qur'an. Menurut teori ini, kemukjizatan alQur'an terutama terletak pada susunannya. Yang membedakan ayat-ayat al-Qur'an dengan prosa atau puisi berbahasa Arab pada umumnya adalah susunannya. Susunan bahasa al-Qur'an berada di level sempurna dari seluruh aspek analisis kebahasaan; satu level yang tidak terjangkau oleh kemampuan manusia seberapapun jeniusnya dalam menggubah susunan bahasa.

Untuk menjelaskan suara bahasa, penulis merujuk ke teori formasi suara yang dikembangkan terutama oleh linguis Arab terkemuka, Tamam Hassan. Formasi suara bahasa, menurut Tamam Hassan, berada di urutan pertama dalam mengenali bahasa Arab; berada di level pertama dari tiga level pemerolehan bahasa Arab yang terdiri dari: pengenalan (ta'arruf), penguasaan (isti'ab) dan pendalaman rasa (tazawwuq). Formasi suara itu terdiri dari unsur makharij al-huruf, sifat huruf, syllable, dan intonasi. Dengan mengenali seluruh unsur ini, seseorang sudah berada di level pertama dalam penguasaan bahasa Arab karena ia menjadi tahu karakter susunan suara dalam bahasa Arab yang terdiri atas posisi satu huruf dengan huruf sebelum dan sesudahnya. Ada huruf yang bisa berdekatan; ada juga yang selalu berjauhan.

Sementara itu, untuk memahami hubungan suara dan makna, penulis merujuk kepada teori relasi natural ('alāqah țabi'iyyah) antara suara dan makna yang di era klasik diintrodusir oleh ahli bahasa Arab, Ibnu Jinnī dan di era kontemporer banyak dielaborasi oleh Dr. Hassan Abbas. Yang terakhir ini bahkan menulis satu buku khusus berjudul: Khașa'iș al-Hurūf al-Arabiyyah wa Ma'āniha (Karakter Huruf Arab dan Maknanya)untuk membuktikan bahwa setiap huruf Arab memiliki sifat yang mengindikasikan maknanya. Artinya, ketika huruf-huruf ini membentuk kata dan kemudian kalimat, susunan suaranya melambangkan makna yang hendak ditunaikannya. Inilah basis teori yang menjelaskan betapa paripurnanya keutuhan suara/nada dan makna dalam susunan bahasa Al-Qur'an. Dus, suaranya saja sudah menggambarkan maknanya; apalagi kalau analisisnya meluas ke wilayah morfologi, sintaks dan semantiknya.

\section{Metode Penelitian}

Pendekatan penelitian yang digunakan dalam tulisan ini adalah pendekatan kualitatif dengan jenis penelitian pustaka (library research). Penelitian kualitatif dalam hal ini digunakan terutama dalam pengertian pendekatan naturalistik untuk memahami fenomena dalam "suatu latar yang berkonteks khusus". ${ }^{1}$ Latar khusus yang dimaksud adalah bahasa al-Qur'an. Latar yang lebih khusus lagi adalah nada atau suara dalam bahasa al-Qur'an.

Untuk memahami latar khusus itu, penulis merujuk kepada dua sumber primer yaitu karya-karya yang terkait aspek suara dalam bahasa dan karya-karya yang membahas kemukjizatan susunan bahasa al-Qur'an, terutama susunan suara

1 Lexy J. Moleong, Metode Penelitian Kualitatif, Bandung: Rosdakarya, 2015, 5. 
bahasanya. Dari penelusuran atas sumber-sumber tersebut, penulis melakukan pengumpulan, pengelompokan, analisis dan penyimpulan. Basis kajian yang dijadikan paradigma adalah dua disiplin ilmu, yaitu fonologi dan semantik: fonologi untuk memahami aspek bunyinya dan semantik untuk memahami aspek maknanya.

Agar sesuai dengan fokus masalah yang diteliti, penulis membangun alur bahasan mulai dari mendiskusikan urgensi suara dalam pewahyuan al-Qur'an; dilanjutkan dengan kenyataan natural bahwa susunan bahasa al-Qur'an adalah kunci utama memahami kemukjizatannya dan suara mengambil bagian pertama dan utama dalam susunan dimaksud. Selanjutnya penulis akan mencoba membuktikan bahwa relasi bunyi/suara bahasa dengan makna ayat-ayat al-Qur'an bersifat natural bukan konvensional. Di bagian akhir pembahasan, penulis akan mengambil beberapa contoh ayat al-Qur'an yang menggambarkan dengan paripurna seluruh postulat yang dibangun dalam tiga bagian sebelum dalam satu alur utuh yang hendak menjawab fokus masalah dalam penelitian.

\section{Hasil dan Pembahasan}

\section{Urgensi Suara Dalam Pewahyuan Al-Qur'an}

Al-Qur'an menceritakan dirinya sendiri. Tentang bagaimana ia diwahyukan. Malaikat Jibril membawa wahyu dari Allah, membacakannya untuk ditirukan oleh Rasulullah, Muhammad SAW, persis seperti didiktekan, dengan tempo sedang (tartill). Selebihnya Allah sendiri yang menjamin bahwa wahyu yang dibaca oleh Rasulullah itu akan tetap terhimpun tanpa cacat di dada Rasulullah, Muhammad SAW. Begitulah seterusnya Rasulullah, Muhammad SAW mengajarkan, persisnya membacakan, alQur'an kepada para sahabatnya: secara lisan, dari suara ke suara. Dari generasi ke generasi, acuan transimisi al-Qur'an adalah suara, secara lisan, bukan secara tulisan. Itulah yang dimaksudkan sebagai "al-Qur'an diturunkan melalui medium suara, nazala al-Qur'anu nuzūlan șautiyyan".

Suaralah sebelum yang lain. Fi al-bad'i kānat al-Așwat. Begitulah nature pewahyuan al-Qur'an. Seluruh ayat al-Qur'an, dari awal sampai akhir, diturunkan melalui medium suara. Bukan sembarang suara, tetapi suara yang bernada, suara yang berharmonisasi dengan makna; suara yang membawa pesan ketuhanan; suara yang menembus pendengaran, menghunjam ke dalam hati, tersimpan di dada para penghapalnya dari masa ke masa sampai akhir masa; suara yang satu frekuensi dengan suara alam yang paling murni; satu frekuensi dengan gelombang elektromagnetik sel-sel tubuh manusia yang paling sehat; suara yang menundukkan hewan, tumbuhan, gunung, langit dan bumi; suara yang menawan para Jin yang sungguh-sungguh menyimaknya hingga mereka tidak kuasa untuk tidak tunduk kepada Sang Pencipta. ${ }^{2}$

Hanya egoisme dan kesombonganlah yang membuat para penyair Arab, mereka yang terkenal sebagai bangsa yang di darahnya mengalir puisi, sajak dan 
syair, mengingkari hati nuraninya untuk tunduk kepada Sang Pencipta. Suara alQur'an menagih telinga mereka untuk terus menerus mendengarkannya, menawan hati mereka untuk terus menerus mencari yang baru dari ayat-ayatnya, membuat mereka sembunyi-sembunyi secara terpisah tetapi berbarengan untuk menikmati keindahan suara al-Qur'an. Al Walīd Ibn al-Mugīrah, pemuka Arab ternama itu membuat testimoni setelah mendengar Rasulullah membaca Q.S. Gāfir (40): 1-3:

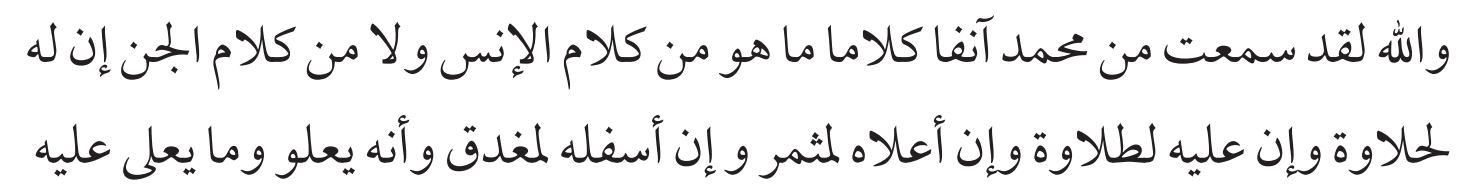

Demi Allah, baru saja saya mendengar dari Muhammad ucapan yang bukan ucapan manusia, tidakjugajin. Ucapan itu manis dan indah. Atasnya berbuah lebat. Bawahnya sangat subur. Ia tinggi tak tertandingi. ${ }^{3}$

Labīd Ibn Rabī’ah, penyair terkemuka itu, menjawab Amīr al-Mu'minīn Umar Ibn al-Khatțab tentang kenapa dia meninggalkan syair sama sekali setelah dia masuk Islam bahwa Surat al-Baqarah saja sudah mencukupkannya dari seluruh syair yang pernah ditekuninya. ${ }^{4}$

Mażhūl. Para tokoh dan penyair Arab-Quraisyitu kelimpungan menilai alQur'an demi mempertahankan keyakinan mereka. Mereka menyebut al-Qur'an itu sihir tapi tidak seperti sihir; kegilaan tapi tidak memiliki ciri-ciri kegilaan; mantra para dukun tapi tidak seperti mantra. Suara al-Qur'an tidak ada dalam semua referensi yang pernah mereka kenal. Ini digambarkan oleh Q.S. al-Muddatstsir (74): 18-26. Walhasil, wajah-wajah mereka mengkerut dan putus asa. Tak kuasa menandingi al-Qur'an, karena al-Qur'an memang tak tertandingi. Ia adalah mukjizat. Susunan bunyi, kata, kalimat dan teksnya adalah mukjizat. Maknanya adalah mukjizat. Ilmunya adalah mukjizat. Informasinya adalah mukjizat. Keseluruhannya adalah mukjizat. Ar-Rāfí̄ menyebut:

$$
\begin{aligned}
& \text { ما أشبه القرآن الكريم في تركيب إعجازه وإعجاز تركيبه بصورة كلامية من نظام } \\
& \text { الكون الذي اكتنفه العلم)ء من كل جهة، وتعاوروه من كل ناحية، وأخلقو اجو انبه } \\
& \text { بحثا وتفتيشا، ثم هو بعد لا يز ال عندهم على كل ذلك خلقا جديدا ومر اما بعيدا }
\end{aligned}
$$

Alangkah persisnya Qur'an yang mulia ini dalam susunan kemukjizatan dan kemukjizatan susunannya dengan susunan alam semesta yang dikaji oleh para ilmuwan dari segala sisi; dibuatkan penelitian dari segala aspek. Namun setelah itu

3 ar.wikipedia, 2018.

4 ar.wikipedia, 2018. 
semua, mereka menemukannya sebagai sesuatu yang baru dan capaian pengetahuan yang masih jauh untuk direngkuh.'

Al-Qur'an sendiri menyebut dirinya sendiri sebagai "ahsan al-hadits", ucapan yang paling baik; ucapan yang membuat bulu roma orang-orang beriman bergidik; ucapan yang membuat hati mereka bergetar tunduk kepada kekuasaan Allah; ucapan yang gunung sekalipun tidak kuasa menahan diri selain tunduk dan berguncangkarena takut kepada-Nya; ucapan yang menjadi tugas Rasulullah SAW untuk dibacakan kepada umatnya; ucapan yang bagai cahaya menghapus kegelapan dan menggantinya dengan keterangbenderangan; ucapan yang diwahyukan selama sekitar 22 tahun untuk terus menerus menguatkan hati, menyegarkan batin dan memperbaharui semangat Rasulullah SAW untuk menyelamatkan umat manusia dari kesesatan demi kesesatan; ucapan yang menjadi warisan terbesar Rasulullah, Muhammad SAW dan menjadi jaminan umatnya hingga akhir zaman untuk tidak tersesat di jalan gelap; ucapan yang menjadi pelita bagi umat manusia untuk menempuh jalan terang dalam hidup mereka. ${ }^{6}$

Membaca al-Qur'an artinya membunyikan suara al-Qur'an. Itulah rahasia kenapa kitab ini dinamakan al-Qur'an. Ia dibaca dan terus menerus dibaca sejak diturunkan sampai hari kiamat. Syarīf Hādi, di kanal ahl al-Qur'ān menulis:

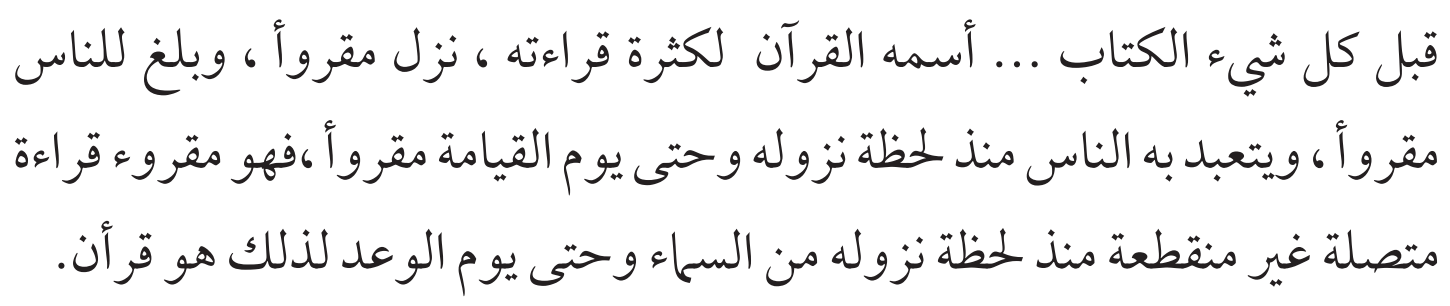

Sebelum lebih jauh, kitab ini... namanya Al-Qur'an karena begitu sering dibaca; turun dengan cara dibaca; disampaikan kepada manusia dengan cara dibaca; dijadikan sarana ibadah sejak diturunkan sampai hari kiamat dengan cara dibaca. Ia terus menerus dibaca tanpa putus sejak diturunkan sampai hari kiamat. Karena itulah ia (disebut) qur'an (bacaan). ${ }^{7}$

Tak pelak lagi, sebelum menjadi kitab dalam bentuk tulisan, al-Qur'an adalah suara yang dibacakan, didiktekan, diajarkan dan diwariskan dari generasi ke generasi hingga hari akhir. Dan dalam bacaan itu, suara mencari tulang punggungnya: suara yang menjadi mukjizat; suara yang bernada; suara yang satu gelombang frekuensi dengan suara alam semesta yang paling murni sehingga mudah menyatu dan dihafalkan oleh mereka yang berhati bersih; suara yang kemudian disimbolkan dalam huruf, ditulis dengan rasm usmani, dan keseluruhannya menjelma menjadi mushaf

5 Al-Qaț̣an, Mannā’, Mabāhis fi Ulūm al-Qur'ān, Cairo: Maktabah Wahbah, 250.

6 Q.S. Al-A'rāf (7): 157

7 Syarīf Hādi, “Adillah Nuzūl al-Qur'ān Masmū'an”, http://www.ahl-alquran.com/arabic/ show_article.php?main_id=3464. 
dalam bentuk kitab suci al-Qur'an yang dibukukan. Disinilah urgensi suara dalam pewahyuan al-Qur'an.

\section{Dari Suara Susunan Alquran Bermula}

Materi kebahasaan al-Qur'an tidak berbeda dengan segala jenis teks berbahasa Arab; huruf, kata dan kalimatnya adalah huruf, kata, dan kalimat bahasa Arab. Yang berbeda adalah susunannya; susunan huruf yang membentuk kata; susunan kata yang membentuk kalimat; dan susunan kalimat yang membentuk teks. Yang berbeda adalah huruf apa yang datang sebelum dan setelah huruf tertentu; kata apa yang berada sebelum dan setelah kata tertentu; kalimat apa yang eksis sebelum dan setelah kalimat tertentu. Susunan seluruh unsur inilah yang menjadi rahasia kemukjizatan al-Qur'an. Susunan yang berada di luar kemampuan manusia dan jin untuk menyusunnya meskipun sekedar satu ayat; meskipun mereka bahu membahu untuk mengusahakan pewujudannya; meskipun mereka mengusahakan dulu, sekarang, nanti dan sampai kapanpun. ${ }^{8}$

Suara dilambangkan dengan huruf. Huruf belum berbunyi jika berdiri sendiri. Ia baru berbunyi jika dirangkai dengan huruf sebelum dan sesudahnya. ${ }^{9}$ Suara yang dilambangkan oleh huruf itu memiliki makhraj dan sifat. Huruf-huruf bahasa Arab terdistribusi ke dalam lima tempat keluar: rongga mulut (jauf), tenggorokan (halq); lidah (lisān), kedua bibir (syafatain), dan batang hidung (khaisyum). Sifat-sifat huruf beranjak dari lemah, sedang, dan kuat. Ada lima sifat yang saling berlawanan: jelas (jahr) $><$ samar (hams); kuat (syiddah) $><$ lunak (rakhwah); terangkat (isti'la' ') $><$ turun (istifāl); terbuka (infitāh) $><$ tertutup (ithbāq); dan tertahan (ișmāt) $><$ lancar $(i \dot{z} l \bar{a} q)$. Sifat yang berlawanan ini masih ditambah dengan 9 sifat yang tidak ada lawannya, yaitu: tawassut (tengah antara syiddah dan rakhwah); layyin (lunak); inhiräf (condong); takïir (mengulang-ulang); șafï (siul); tafasysyi (menyebar); qalqalah (goncang); istițālah (memanjang); dan gunnah (berdengung). ${ }^{10}$

Tamām Hassan, linguis Arab terkemuka berkebangsaan Mesir, menyebut bahwa karena makhraj dan sifat huruf yang berbeda-beda inilah susunan suara kebahasaan dalam bahasa Arab tampil beragam dari yang paling buruk sampai yang paling indah bahkan dengan keindahan di luar kuasa manusia. Ada huruf-huruf yang saling tidak bisa bertemu dalam satu susunan; ada huruf-huruf yang saling berharmonisasi menyusun bunyi yang indah; ada huruf-huruf yang menyusun keindahan bunyi dengan mengorbankan makna; dan ada huruf-huruf yang saling bersesuaian antara keindahan bunyi dan kecanggihan makna yang hendak ditunaikan. Tabel berikut menggambarkan penjelasan Tamām Hassāndimaksud: ${ }^{11}$

8 Q.S. Al-Isrā' (17): 88.

9 Abd ar-Rahmān Budar', “Al-Farq Baina al-Harf wa al-Saut”, https://www.m-a-arabia.com/site/13186.html.

10 Dadan Ahmad Ramdlan, "Makhroj dan Sifat-Sifat Huruf Hijaiyyah dalam al-Qur'an, http:// dadanar.blogspot.com/2013/11/makhroj-dan-sifat-sifat-huruf-hijaiyyah.html.

11 Tamām Hassān, At-Tamhīd fi Iktisāb al-Lugah al-Arabiyyah li Gair an-Naṭiqīna Bihā, Mekah: Jami'ah Umm al-Quro, 1984, 18. 
Keutuhan Nada dan Makna... [Dedy Wahyudin, Djuaini]

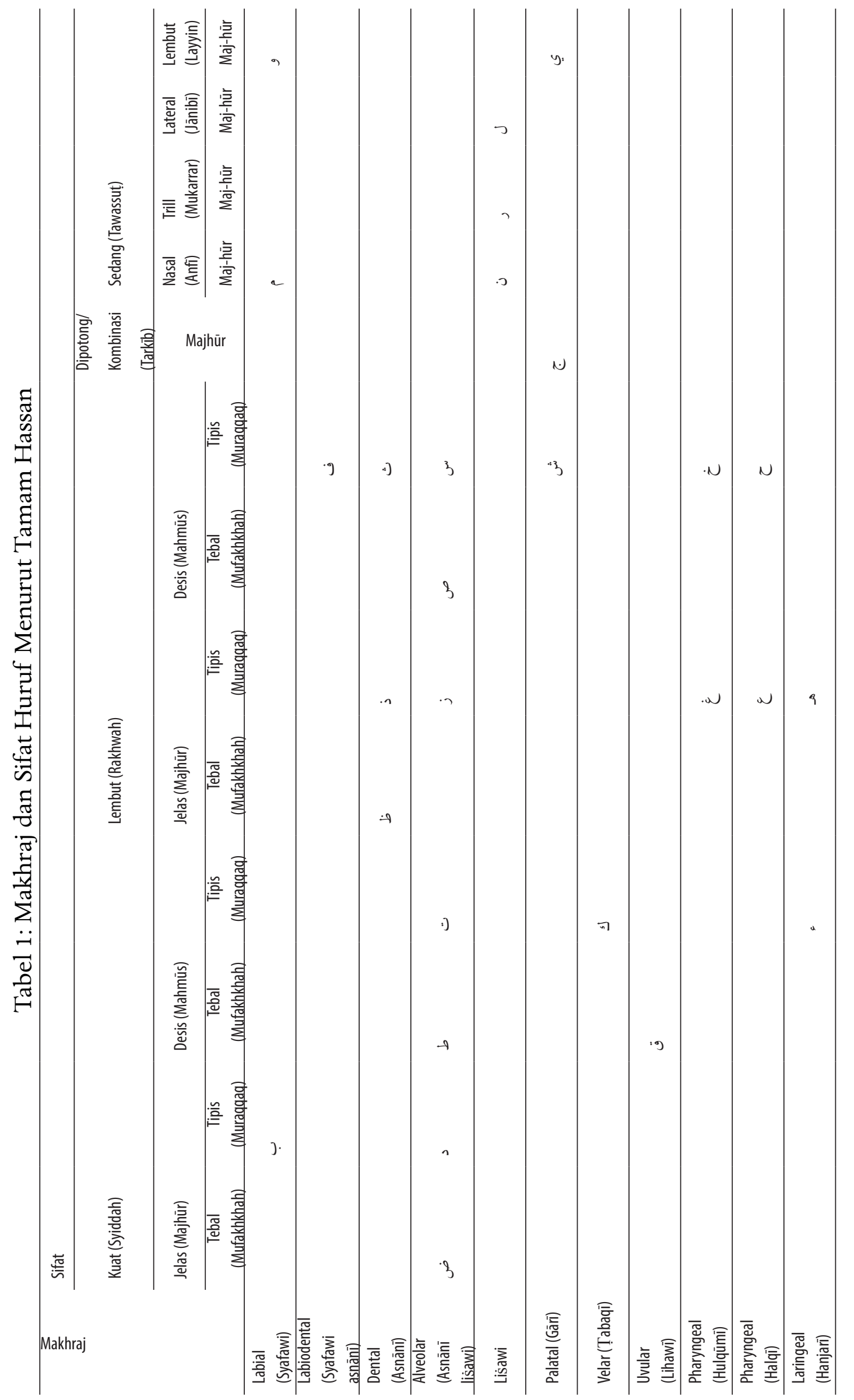


Tabel di atas menjelaskan titik-titik perbedaan dan persamaan antar huruf. Ada huruf yang sama sifatnya tetapi berbeda makhraj-nya; sama makhraj-nya tetapi berbeda sifatnya. Misalnya, huruf ba' (ب), mim ( () dan waw (و), makhraj-nya sama tetapi hurufnya berbeda; sedangkan huruf fa' (ف), tsa' (ث) dan sin (س), sifatnya sama tetapi makhraj-nya berbeda. Mengenali susunan bahasa Arab bisa dimulai dari susunan bunyi bahasanya. Untuk itulah, indikator yang dipakai oleh para ahli bahasa Arab adalahtalab al-khiffah (economy of effort, mencari yang ringan diucapkan). Indikator ini selanjutnya terderivasi ke dalam tiga prinsip, yaitu: 1) karahiyat tawālì al-mis̀lain aw al-mutaqāribain, pengulangann dua huruf yang sama atau serupa tidak disukai; 2) karahiyat tawāli al-mutanāfirain/pengulangan huruf yang sifatnya berlawanan tidak disukai; dan 3) ta'kid darurat al-farq, keharusan menegaskan perbedaan bunyi huruf. Dalam hal ini, Tamām Hassān memberi catatan:

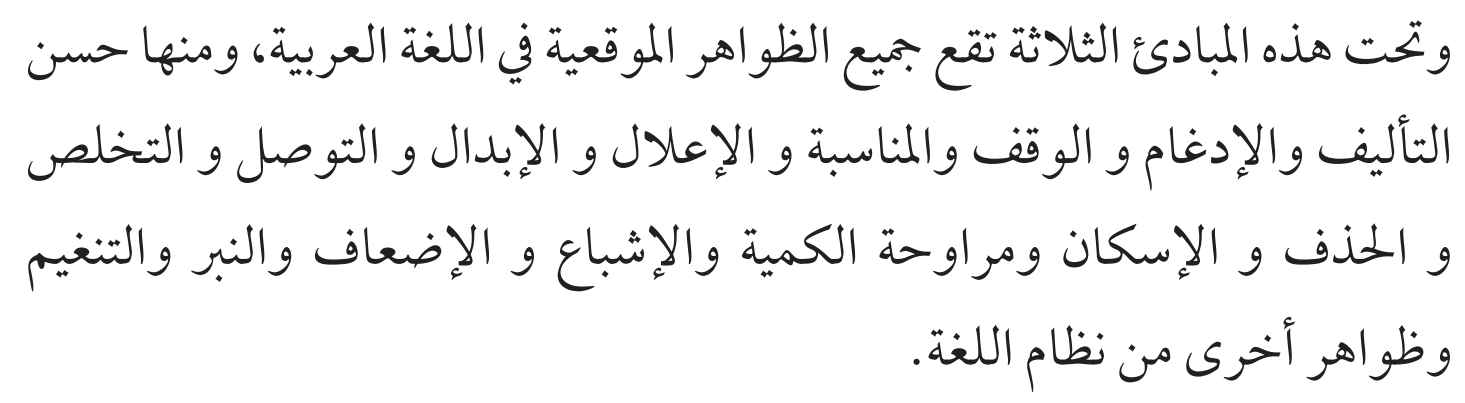

Di bawah tiga prinsip inilah seluruh fenomena posisi suara dalam bahasa Arab berada di antaranya: susunan yang baik, idgãm, waqf, kesesuaian huruf dengan sebelum dan setelahnya, i'lãl, mengganti huruf dengan huruf lain, meminta bantuan huruf tertentu untuk menyambung bacaan, pengabaian, membuang huruf, mensukunkan huruf, pengaturan atau intervensi pada jumlah huruf, menyempurnakan bacaan, mendobelkan huruf, penekanan suara, intonasi, dan fenomena-fenomena lain dalam sistem bahasa. ${ }^{12}$

Selain makhraj dan sifat huruf, sistem bunyi bahasa Arab termanifestasi pada tiga sub-sistem yaitu: 1) maqta' atau syllable adalah satuan bunyi bahasa Arab yang terdiri atas fonem yang menyusun struktur. Berdasarkan penelitian, maqta' bahasa Arab terdiri dari unsur inti (nucleus, nuwat al- maqta' dan unsur-unsur pendukung (marginal factors). Vokal (harakat,șawa'it)adalah inti dan konsonan (șawāmit) adalah unsur pendukung, sehingga jumlah maqta' dalam satu kata adalah sejumlah harakāt-nya ; 2) nabr(stress, penekanan bunyi) adalah power atau tingkat kenyaringan (loudness) dari satu maqta'dalam lafaz tertentu; dan 3) tangīm(intonasi) adalah serial frekuensi suara (pitch) yang berbeda tinggi rendahnya yang diselingi oleh "berhenti sebentar"(non final pause) atau "berhenti tetap" (final pause). Intonasi kalimat berita, pertanyaan, perintah, ataueksklamasi biasanya berbeda-beda. ${ }^{13}$

12 Ibid, 25.

13 Salmān HassanAl-Ān̄̄,At-Tasykīl as-Șauṭi fi al-Lugah al-Arabiyyah Funulujiya alArabiyyah, Jeddah: an-Nādī al-Adabī al-Ṡaqafì, 1983, 131-147. 
Sistem suara yang merupakan sub-sistem bahasa Arab secara keseluruhan rupanya muncul di sub-sistem-sub sistem lain dari bahasa Arab, mulai dari subsistem kata (morfologis), sub-sistem kalimat (sintaksis) sampai dengan sub-sistem makna (semantis). Artinya, fenomena bunyi bahasa adalah fenomena given dalam batang tubuh bahasa Arab. Sistem bunyi yang merangkai makna adalah salah satu keistimewaan bahasa Arab. Hubungan korespondensi ini menjadi sempurna dalam susunan bunyi dan makna ayat-ayat al-Qur'an. Hal inilah yang terutama dibuktikan misalnya oleh Ibnu Jinni, az-Zamakhsyari, Sayyid Qutb dan Mușțafa Șadiq ar-Rāfi'̄. Jka mengacu ke teori nazm, susunan bunyi al-Qur'an adalah awal dari kemukjizatan susunan al-Qur'an secara keseluruhan.

\section{Korespondensi Susunan Bunyi dan Makna dalam Bahasa Alqur'an}

Sebagai materi kebahasaan, para linguis Arab klasik, mulai dari Ibnu Khalil al-Farāhidi, Sibawaih, Ibnu Jinni, hingga az-Zamakhsyari memastikan bahwa bunyi bahasa Arab berkorespondensi dengan makna. Ibnu Jinni, bahkan menulis satu pasal khusus di kitab al-Khaṣā'iṣ-nya dengan judul: تصاقب الألفاظ لتصاقب المعنى / kesesuaiann sifat suara (lafz) dengan sifat maknanya. Jika tidak secara langsung, suara bahasa itu mempersiapkan situasi (circumstance) yang mengarahkan pendengarnya ke arah makna yang diinginkan. Ini misalnyą digambarkan dalam syair berikut: يُقَضْقضْ / / عَصْلا في أسرَتها الرَّدَى/gemeretak perut (sang sriǵala) karena kelaparan// seperti gemeretak tulang (seseorang) yang diserang cuaca yang sangat dingin. Suara "qaf" (5 kali) dan "ra"” (6 kali) yang dipakai berulang-ulang menunjukkan bunyi perut keroncongan karena kelaparan (qqqrrrrr!). ${ }^{14}$

Jika dirunut ke asal usul lahirnya kata-kata (isytiqāq al-mufradāt), kita akan menemukan teori yang disebut nazariyat al-muhākāt, satu teori yang menegaskan bahwa hubungan kata dengan maknanya adalah hubungan natural ('alāqah țabi'iyyah). Kata-kata lahir dari meminjam bunyi alam yang menggambarkan maknanya. Tabel berikut menggambarkan contoh kata-kata dalam bahasa Arab yang mendukung teori ini: $:^{15}$

Tabel 2 : Contoh Relasi Natural Bunyi dan Kata

\begin{tabular}{|c|c|c|c|}
\hline No & Kata & Asal Bunyi & Contoh Kalimat dan Maknanya \\
\hline 01 & أََََّ & $\begin{array}{l}\text { Bunyi ketika seseorang sakit } \\
\text { tenggorokan }\end{array}$ & 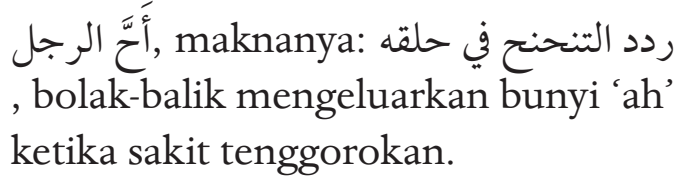 \\
\hline
\end{tabular}

14 Abd al-Rahmān Muhammad Wadelkebeida, "Musiqī al-Kalimāt wa Kalimāt al-Musiqī fi al-Lugah al-Arabiyyah", http://www.wadelkebeida.net/index.php/en/art/250-mseqakalemat.

15 Said Muștafa Abū Țālib, “al-Isytiqāq al-Sawti”.https://www.alukah.net/literature_ language/0/113252/. 


\begin{tabular}{|c|c|c|c|}
\hline 02 & الأزيز & $\begin{array}{l}\text { Bunyi air ketika mendidih di } \\
\text { periuk }\end{array}$ & $\begin{array}{l}\text { أزت السحابة تئز أزا وأزيزا } \\
\text { awan mengeluarkan petir (bunyi } \\
\text { azzz) }\end{array}$ \\
\hline 03 & أَفْ & $\begin{array}{l}\text { Suara yang dikeluarkan oleh } \\
\text { seseorang ketika dia tidak } \\
\text { senang }\end{array}$ & 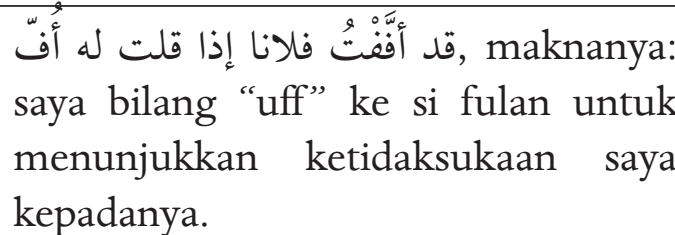 \\
\hline 04 & آَه & Suara orang mengeluh & $\begin{array}{l}\text { آَهَأُوُْوأوْها, artinya: seseorang mengeluh } \\
\text { (mengeluarkan suara: aaah) }\end{array}$ \\
\hline 05 & الجهججهة & $\begin{array}{l}\text { Suara teriakan tentara ketika } \\
\text { berperang }\end{array}$ & $\begin{array}{l}\text { جهُجه, artinya: sangtentarayangsedang } \\
\text { bertempur berteriak (mengeluarkan } \\
\text { suara: jahjah) }\end{array}$ \\
\hline
\end{tabular}

Relasi suara dan makna semacam ini dalam laku bahasa Arab disebut "taqammuṣ", satu fenomena dimana penutur bahasa meresapi makna dan mengekspresikannya dalam lakon penuh (suara, gerakan badan, mimik muka dan seterusnya) secara ekspresif; persis seperti pemain teater atau film yang sedang memerankan tokoh tertentu seolah-olah ia adalah tokoh tersebut. ${ }^{16}$ Proses inilah yang menjelaskan bagaimana proses orang-orang Arab, terutama para pujangga, melahirkan kata-kata bahasa Arab yang suaranya mengisyaratkan maknanya. Dalam proses ini diperlukan rasa yang bening dengan mengaktifkan seluruh panca indera untuk menemukan huruf-huruf yang sesuai dengan rasa yang ditangkap dan mendistribusikannya ke dalam masing-masing dari lima panca indera manusia. Inilah hasilnya: ${ }^{17}$

Tabel 3: Penunjukan Huruf terhadap Makna

\begin{tabular}{|c|c|c|}
\hline No & Makna yang ditangkap oleh indera/rasa & Huruf yang menunjukkannya \\
\hline 01 & Perabaan & ت ت ت ث، د، ذ، ك، م \\
\hline 02 & Pengecapan & 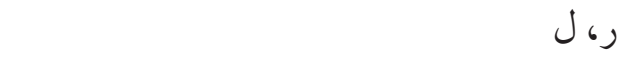 \\
\hline 03 & Penglihatan & ألف، ب، ج، س، ش، ط، ظ، غ، ف، و، ي \\
\hline 04 & Pendengaran & 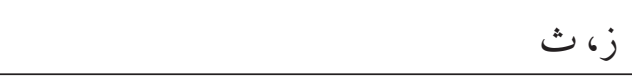 \\
\hline 05 & $\begin{array}{l}\text { Huruf-huruf berasa selain kelompok tenggoro- } \\
\text { kan (gair al-halqiyah) }\end{array}$ & \\
\hline 06 & $\begin{array}{l}\text { Huruf-huruf berasa kelompok tenggorokan (al- } \\
\text { halqiyah) }\end{array}$ & 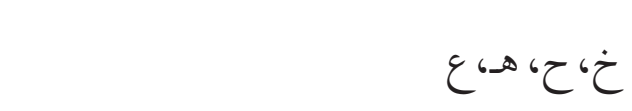 \\
\hline
\end{tabular}

16 http://www.m-a-arabia.com/vb/showthread.php?t=30384, diakses tanggal 08/05/2019, jam 03:32 WITA.

17 Asia Bas'̄̄, Așwāt al-Hurūf al-'Arabiyyah wa Īhā'ātuha al-Hissiyyah fi al-Ma'ājim al'Arabiyyah. Tesis. Algier: Jami’ah al-Arabi Benmahidi, 2010, 54. 
Dr. Hasan Abbas membuktikan bahwa huruf-huruf dalam bahasa Arab berkorelasi positif dengan makna yang ditunaikannya; bunyinya melambangkan maknanya;maknanya ada di satuan bunyi dan hurufnya. Misalnya kata عشق terdiri

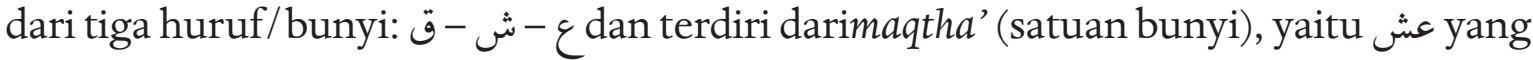

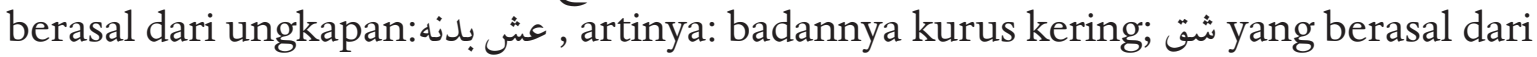
ungkapan: شقالشيء, artinya: ia merobek atau mengobrak-abrik sesuatu. Selanjutnya, huruf $ع$ munjukkan makna: mengikat; huruf ش menunjukkan makna: menyebar; dan huruf ق menunjukkan makna:kekuatan, perlawanan dan ledakan suara. Rangkain huruf kata ini bermakna bahwa عشق berarti sesuatu yang mengikat-menambat ('ain); dengan segala tekanan perasaan yang menyebar (syin); dan dengan kekuatan dan gejolak yang bergelora ( $q \bar{a} f)$. Sedangkan rangkaian bunyinya bermakna: perasaan menyiksa yang dibarengi dengan badan yang kurus kering dan hati yang berantakan. Artinya, dari materi huruf dan satuan bunyi tergambar persis bagaimana kondisi orang yang sedang dirundung cinta dan rindu berat kepada kekasihnya. ${ }^{18}$

Beginilah gambaran susunan nada dan makna bahasa Arab secara umum, apatah lagi dengan susunan nada dan makna al-Qur’an. Jika kadangkala ada yang dikorbankan dalam persistensi korespondensi nada dan makna dalam susunan puisi atau prosa bahasa Arab; artinya keindahan bunyi kadangkala mengorbankan makna atau makna yang adiluhung kadangkala mengorbankan keindahan susunan nada maka tidak demikian dengan al-Qur'an. Setiap huruf ayat-ayat al-Qur'an sudah persis berada di tempat yang tepat untuk mendukung kesatuan harmonis nada dan maknanya. Artinya, kalau satu huruf saja dari ayat tertentu diganti dengan huruf lain maka akan terlihat cacat pada susunannya, apakah itu susunan nadanya atau susunan maknanya. Muṣțafā Șādiq ar-Rafi’’ dalam hal ini menulis:

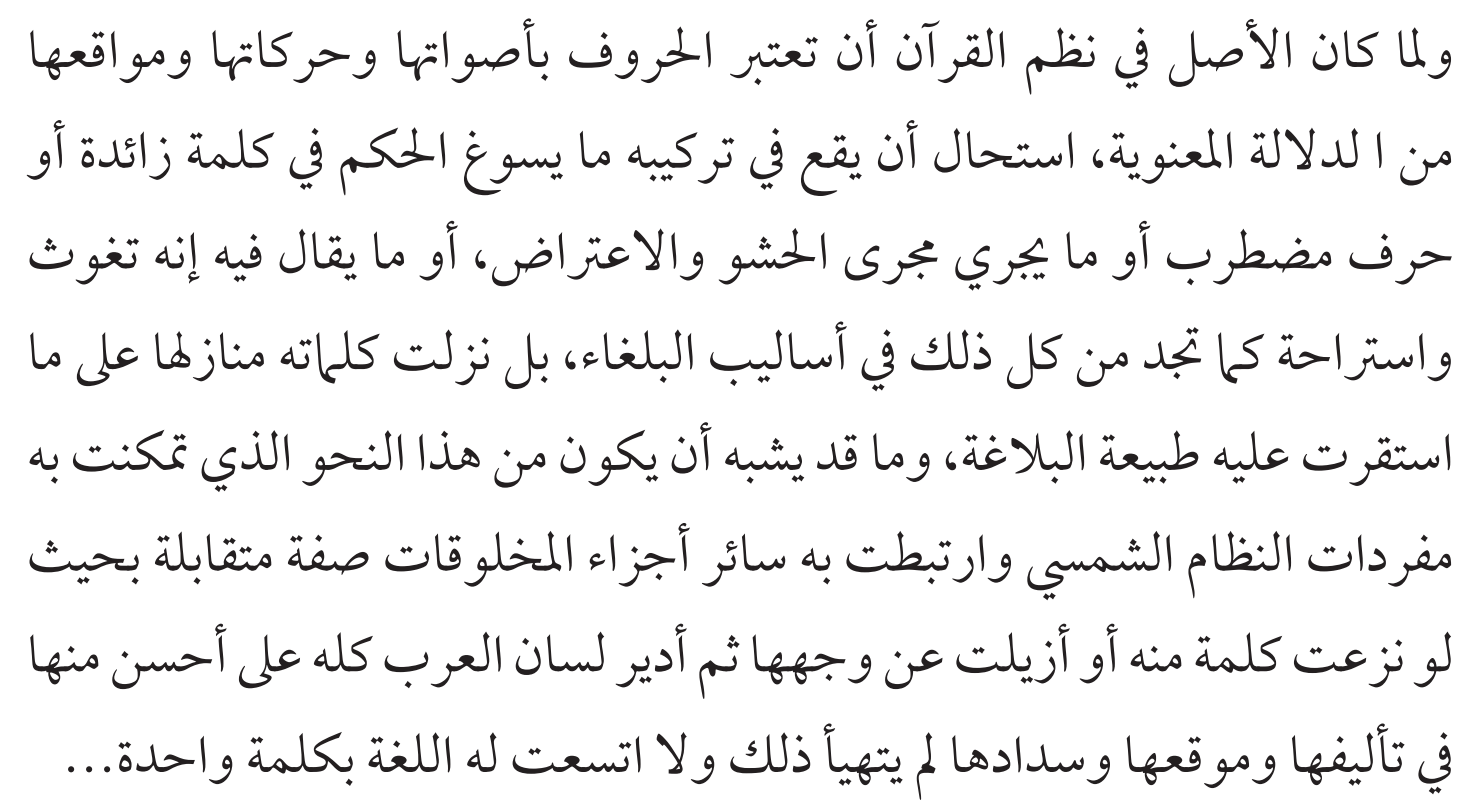

18 Hasan Abbas, Khașa'iṣ al-Hurūf al-Arabiyyah wa Ma'ānīha, Damskus: Ittihād Kuttāb al'Arab, 1998, 174. 
Jika dasarnya dalam "nazm al-Qur'ān" adalah bahwa huruf-huruf dengan suara, harakat dan posisinya merupakan bagian dari penunjukkan maknanya maka menjadi mustahil terjadi dalam susunan al-Qur'an ada kata tambahan, huruf yang tidak sesuai atau sesuatu yang sekedar muncul sebagai sempalan atau bukan pada tempatnya (karena kelemahan atau kejenuhan penyusun) seperti yang biasa anda temukan pada susunan karya para pujangga. Tetapi kata berada di tempat yang seharusnya menurut ilmu balagah (muțābaqah al-maqāl li muqtad̄a al-häl/ujaran sesuai persis dengan kebutuhan)sebagaimana satuan planet yang terkait satu sama lain dalam sistem tata surya. Artinya, kalau satu kata dicabut atau diganti tempatnya lalu seluruh kata dalam Bahasa Arab dicari untuk menggantikannya maka satu katapun tidak bisa menunaikannya... ${ }^{19}$

Hal senada diungkap oleh Sayyid Quṭb. Begitu anda memasuki ayat-ayat alQur'an, anda lebih dulu terpana oleh nada dan imaginasi yang digambarkannya. Dalam berbagai karya Sayyid Qutb, terutama "at-Tașwir al-Fanni fi al-Qur'ān” dan kitab tafsir "fi Zilāl al-Qur'ān", beliau memastikan bahwa bunyi (jars) dan siluet (zill) al-Qur'an langsung menggambarkan makna ayat bahkan sebelum anda memikirkan dan merungkannya. Harmonisasi keduanya (nada dan makna) terjadi sedemikian rupa sehingga kedua-duanya tertunaikan secara sempurna. Ini tidak terjadi pada karya pujangga Arab, betapapun genius dan berpengalamannya.

Sayyid Ali Mīr Lūhī dan Mājid an-Najjār menulis:

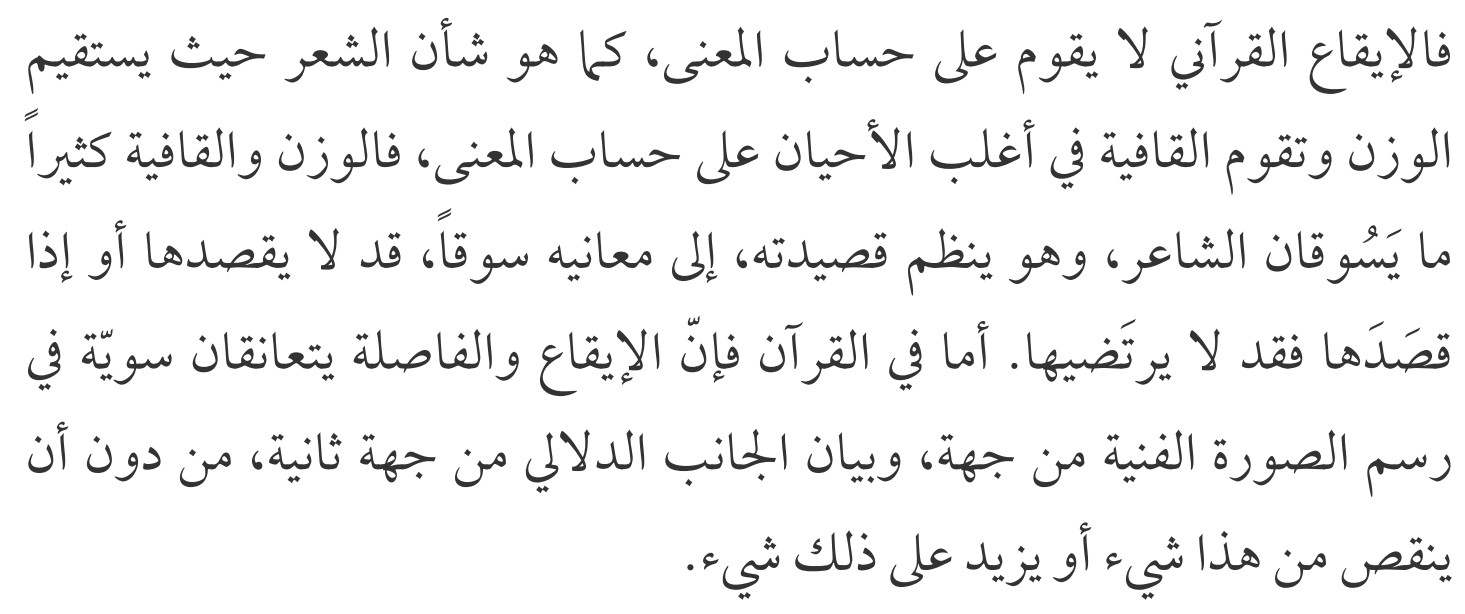

Ritme Qur'ani sama sekali tidak mengorbankan makna seperti yang terjadi pada kasus syair dimana seringkali wazn dan qäfiyah (padanan ritme pada syair) eksis dengan mengorbankan makna. Wazn dan qäfiyah seringkali menggiring penyair ketika menggubah syairnya menuju makna; boleh jadi makna itu memang dimaksudkannya atau diniatkan tetapi tidak memuaskannya. Sementara di dalam al-Qur'an, ritme dan pemisah(fäșilah, pause) saling mendukung dalam menggambar bentuk keindahan

19 Mustafa Sadiq Al-Rafi'i, I'jaz al-Qur'an wa al-Balagah an-Nabawiyyah, Beirut: Dar alKutub al-Arabi, Cet. IX, 1973, 224-225. 
di satu sisi dan aspek penunjukan makna di sisi lain tanpa berkurang di sini atau bertambah di sana. ${ }^{20}$

\section{Kalam Min Dzahab: Susunan Emas Ujaran Al-Qur'an}

Mari kita buktikan rangkaian narasi di atas dengan bukti beberapa ayat atau potongan ayat al-Qur'an. Lihatlah bagaimana dunia membuka diri dari segala penjuru sampai membuat manusia terlena hingga tiba-tiba jasadnya sudah diusung dalam keranda untuk dimasukkan ke liang kubur. Dalam sistem vokal (vocal system), tiga belas kalivokalterbuka berulang di Q.S. at-Takātsur (102): 1-2 vokal terbuka(a) yang mengindikasikan betapa dunia membuka diri tak alang kepalang dan manusia terbahak-bahak menikmatinya hingga tiba-tiba datang vokal tertutup (i) persis di kata al-maqābir yang melambangkankan kejadian tiba-tiba manusia yang terlena tadi sudah harus diturunkan masuk ke liang kubur. ${ }^{21}$. Allah SWT berfirman:

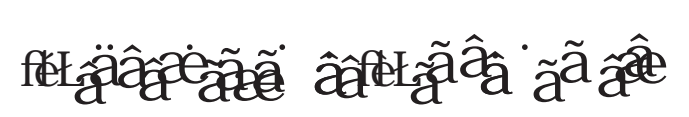

Bermegah-megahan telah melalaikan kamu. Sampai kamu masuk ke dalam kubur(Q.S. at-Takāisur (102): 1-2)

Perhatikanlah juga bagaimana ayat pertama dimulai dengan suara ledakan hamzah yang keluar dari makhraj yang paling dalam yaitu pangkal tenggorokan (hanjarah, larynx) dengan sifat huruf kuat (syiddah);suara letupan yang hendak memperingatkan manusia untuk mawas diri bahwa akanada sesuatu yang sangat penting untuk diperhatikan. Lantas setelah itu, muncul bunyi tiga vokal terbuka sedang

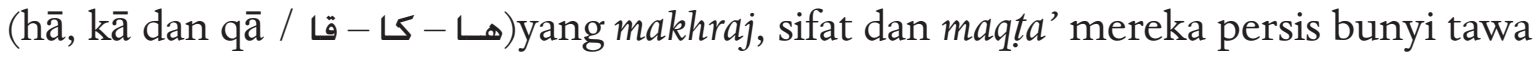
terbahak-bahak orang-orang yang terlena dalam perlombaan dunia; tawa yang tidak mendatangkan ketenangan hati sebagaimana ditunjukkan oleh berulangnya huruf $t a$ ' yang mengisyaratkan hidup yang goncang tanpa ketenangan. ${ }^{22}$ Namun demikian, riwayat tawa terbahak-bahak ini tidak panjang. Ia harus ditutup oleh sempitnya kuburan sebagaimana ditunjukkan oleh tiga vokal semi terbuka (u: zurtumu) yang diucapkan dengan bentuk bibir yang sempit dan dipungkasi oleh vokal tertutup (i: Imaqāaira) sebelum kelak dibangkitkan kembali untuk memasuki alam akhirat yang dilambangkan oleh vokal terbuka lagi (a: Imaqabira). ${ }^{23}$

Alunan nada dua ayat ini menunjukkan perjalanan manusia yang terlena oleh kehidupan dunia; tertawa terbahak-bahak tetapi bercampur dengan keresahan dan kegoncangna jiwa; keindahan yang seolah tak akan sirna itu hilang sekejap ketika ia

20 Sayyid Ali Mīr Lūhī dan Mājid Al-Najjār, "Al-I'jāz al-Șauți fi al-Qur’ān al-Karīm: Naẓrah fi Kutub al-Bāhisīin al-Arab al-Qudāmā wa al-Mu'āṣirīn”, Majallah Ahl al-Bait no. 9: 31-56 http://abu. edu.iq/research/articles/13145, 2009, 54.

21 Mahdi 'Inād Ahmad Qabha, At-Tahlīl al-Șawți li al-Naș, Tesis. Palestina: Jami'ah al-Najah alWatniyah, 2011, 80 .

22 Ibid, 77-78.

23 Ibid, 80. 
harus "ziarah" ke kuburan yang sempit; kemudian ia dibangkitkan dari kesempitan itu untuk memasuki alam akhirat yang baginya jauh lebih sempit tetapi akan dideritanya berulang-ulang untuk selamanya.

Nada al-Qur'an kadang-kadang datang begitu kuatnya untuk menggambarkan kedahsyatan hari kiamat ketika bumi bergoncang dan terbalik sebagaimana digambarkan dalam firman Allah SWT:

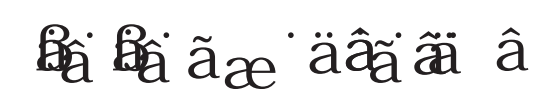

Jangan (berbuat demikian). apabila bumi digoncangkan berturut-turut(Q.S. al-Fajr (89): 21)

Kata د د yang berulang hendak menunjukkan begitu mengerikannya suara bumi yang bergoncang dan terbalil: dek-dek-dek!. Huruf د ini memiliki sifat yang kuat (syiddah) dan paling sesuai untuk menggambarkan makna kedahsyatan dan kekuatan yang bersifat material. ${ }^{24}$

Di kala lain, nada al-Qur'an seperti berbisik bagaikan suara heningnya malam dan beningnya subuh sebagaimana firman Allah SWT:

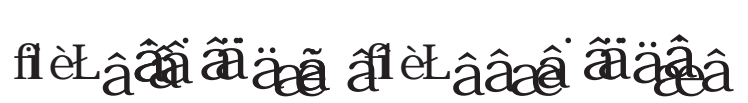

Demi malam apabila telah hampir meninggalkan gelapnya, dan demi subuh apabilafajarnya mulai menyingsing(Q.S. at-Takwīr (81): 17-18)

Malam tidak pernah berlalu tiba-tiba. Ia beringsut perlahan. Kegelapan malam beranjak dari pekat, semakin tipis dan akhirnya sirna digantikan fajar. Huruf sīn yang berulang-ulang di dua ayat ini bertutur tentang tabiat malam dan subuh. Malam adalah waktu istirahat paling ideal. Dalam tidur, manusia dipeluk malam dengan lembut. Ketika subuh tiba, malam seperti menarik nafas untuk menggeliat bangun dan meninggalkan tempat untuk digantikan waktu subuh. Subuh adalah waktu paling hening-bening untuk memulai kehidupan. Syekh Rātib Nabulsi mengatakan bahwa huruf sīn selalu menunjukkan sesuatu yang berada di dalam; sesuatu yang menenangkan; sesuatu yang lembut, intrinsik dan personal. ${ }^{25}$

Suara selembut apapun, orang tuli tidak bisa mendengarkannya. Ucapan seringan apapun orang bisu tidak bisa mengucapkannya. Obyek seterang apapun, orang buta tidak bisa melihatnya. Itulah gambaran orang munafik sebagaimana ditunjukkan oleh firman Allah SWT:

24 'Abd al-QādirBin Fatțah, "Balāgah at-Takrār fi al-Qur'ān". https://www.oudnad.net/spip. php?article1115\&lang=ar, 2014.

25 Muhammad RatibAl-Nābulsi, “Ad-Dars: 2 -Surat at-Takwir-Tafsir al-Ayat 15-29, al-Insan

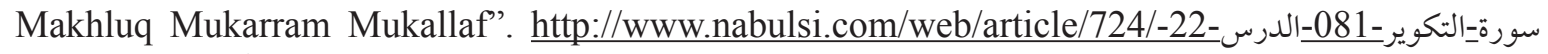
تئسير-الآيات1529,2019. 


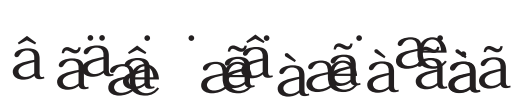

Mereka tuli, bisu dan buta, Maka tidaklah mereka akan kembali (ke jalan yang benar) (Q.S. al-Baqarah (2): 18)

Seluruh analisis sistem suara bekerja pada tiga kata pertama dari ayat ini, yaitu kata: صمب، بكم، عمي. Aspek analisis yang dimaksud adalah: 1) makhraj dan sifat huruf; 2) satuan bunyi (maqta', syllable); 3) tekanan (nabr, stress) dan 4) ritme (īqa')'.

Huruf $s \bar{a} d$ adalah huruf bersuara siul (șafir); suara yang paling sesuai mewakili suara alam. Huruf $b \bar{a}$ 'adalah konsonan bilabial yang jelas dan meletup. Dalam posisi di awal kata, dengan makhraj dan sifatnya, huruf ini paling sesuai untuk menunjukkan suatu yang terbit, baru muncul dan terus mengalir. Huruf 'ainadalah huruf halqī (kerongkongan)yang bersifat kuat sehingga cocok untuk menunjukkan sesuatu yang terang dan jelas. Huruf ini secara otomatis mengantarkan pengucap dan pendengarnya ke kata 'ain yang berarti mata.

Maqta' (satuan bunyi) ayat ini terdiri dari enam satuan sebagai berikut: shum + mun $+b u k+$ mun + 'um $+y u n / /$ / صم + من + بك + من + عم + satuan yang sama persis pada tipe bunyi, vokal dan konsonannya namun masing-masing dipungkasi dengan warna suara yang berbeda: yang pertama, iqlāb; kedua, izhar; dan ketiga $i k h f \bar{a}$ '. Pertanyaannya: bagaimanakah gerangan pemaknaan terhadap berulangnya bunyi tanwin dengan vokal setengah terbuka tiga kali di setiap ujung maqta' dari masing-masing kata; ditambah dengan tekanan pada bunyi dammah di awal setiap maqta' dengan intonasi yang naik di awal maqta' dan turun di akhirnya sebanyak tiga kali berturut-turut? Prof. Dr. Mājid al-Najjār menjawabnya dengan pertanyaan:

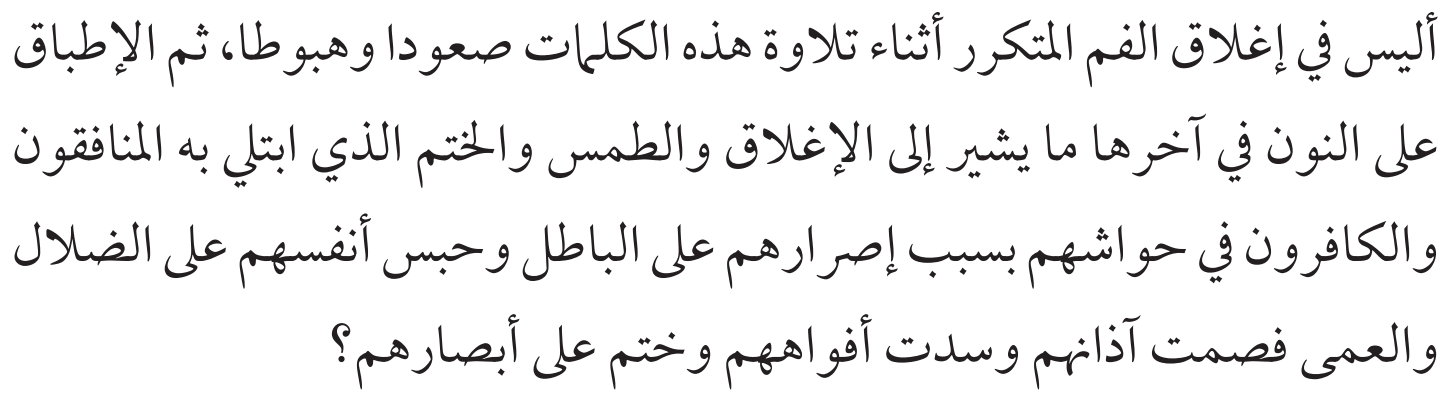

Bukankahpada menutupnya mulut yang berulang-ulang ketika membaca kata-kata ini dengan nada naik dan turun, kemudian (kembali) tertutupnya (mulut) di akhir (setiap maqta') menjadi sesuatu yang menunjukkan ketertutupan, ketertutupan dan ketertutupan yang dialami oleh orang-orang munafik dan orang-orang kafir dalam keterpinggiran hidup mereka oleh karena kengototan mereka dalam kebatilan dan tertahannya diri mereka dalam kesesatan dan kebutaan sehingga telinga mereka tuli, murut mereka terkunci dan pandangan mereka tertutup (buta)? ${ }^{26}$

26 Mājid Al-Najjār, Min Malāmih ad-Dalālah as-Ṣawtiyyah fi al-Qur'ān al-Karīm. Majallah Ahl al-Bait no. 4: 222-249. http://abu.edu.iq/research/journals/ahl-al-bayt/issues/4,2006.Qabha, 


\section{E. Simpulan}

Salah satu ciri khas bahasa Arab adalah kata-katanya membentuk bunyi yang melambangkan relasi naturalnya dengan alam. Relasi natural ini terbentuk dari bunyi huruf yangsifat-sifatnya disesuaikan dengan penunjukan maknanya. Konsekwensinya, bunyi bahasa Arab berkorespondensi dengan makna yang ditunjuknya. Kekhasan inilah yang dikuatkan dan disempurnakan oleh susunan bahasa al-Qur'an. Sub-sistem suara dalam susunan al-Qur'an yang terdiri atas huruf, syllable, tekanan, intonasi dan ritme berkorespondensi secara sempurna dengan makna yang ditunjuki baik secara langsung atau secara simbolik dengan menciptakan atmosfer yang mengkondisikan pembaca untuk memahami makna yang diinginkan melalui pemahaman utuh terhadap sistem suara yang diaplikasikan. Keutuhan nada dan makna dalam susunan bahasa al-Qur'an ini dibuktikan dengan contoh-contoh analisis nada dan makna yang ditampilkan di bagian akhir dari tulisan ini.

Implikasi teoritis dari kesimpulan ini adalah keharusan para pengkaji al-Qur'an untuk semakin detil meneliti kaitan nada dan makna al-Qur'an dalam setiap ayat dalam mushaf al-Qur'an. Dengan demikian, para penikmat bacaan al-Qur'an bukan sekedar menikmati keindahan nada bacaan ayat-ayat al-Qur'an semata tetapi bisa mengaitkannya dengan keagungan pesan ketuhanan yang diembannya. Pendengar bacaan al-Qur'an lantas menjadi faham mengapa bacaan al-Qur'an bisa membuatnya merinding, meneteskan air mata, bahkan mengalami kegoncangan batin yang menuntunnya untuk tunduk dan mengakui kemahabesaran dan kemahakuasaan Allah SWT.

\section{Daftar Pustaka}

Abbas, Hasan, Khașa'iṣ al-Hurūf al-Arabiyyah wa Ma'ānīha, Damskus: Ittihād Kuttāb al-Arab, 1998.

AbūṬālib, Said Muștafa. "al-Isytiqāq al-Sawti". https://www.alukah.net/literature language $/ 0 / 113252 /$.

Al-Ānī, Salmān Hassan,At-Tasykīl as-Ṣauți fi al-Lugah al-Arabiyyah Funulujiya alArabiyyah, Jeddah: an-Nādī al-Adabī al-Śaqafî, 1983.

Bas'ī, Asia, Așwāt al-Hurūf al-'Arabiyyah wa Īhā'ātuha al-Hissiyyah fi al-Ma'ājim al'Arabiyyah. Tesis. Algier: Jami’ah al-Arabi Benmahidi, 2010.

Bin Faț̣ah, 'Abd al-Qādir, "Balāgah at-Takrār fi al-Qur'ān”. https://www.oudnad. net/spip.php?article1115\&lang=ar, 2014.

Budar', Abd ar-Rahmān, "Al-Farq Baina al-Harf wa al-Ṣaut",https: / / www.m-a-arabia. $\mathrm{com} / \mathrm{site} / 13186 . \mathrm{html}$.

Mahdi 'Inād Ahmad, At-Tahlīl al-Ṣawți li al-Naș,. Tesis. Palestina: Jami'ah al-Najah al-Watniyah, 2011, 243. 
Hādi, Syarīf, "Adillah Nuzūl al-Qur'ān Masmū’an”,http://www.ahl-alquran.com/ arabic/show article.php?main id=3464.

Hassān, Tamām, At-Tamhīd fi Iktisāb al-Lugah al-Arabiyyah li Gair an-Natịīna Bihā, Mekah: Jami'ah Umm al-Quro, 1984.

Mīr Lūhī, Sayyid Ali \& Al-Najjār, Mājid, "Al-I’jāz al-Ṣauṭī fi al-Qur'ān al-Karīm: Naẓrah fi Kutub al-Bāhisī̄n al-Arab al-Qudāmā wa al-Mu'āṣirīn”, Majallah Ahl al-Bait no. 9: 31-56 http://abu.edu.iq/research/articles/13145, 2009.

Al-Nabulsi, Muhammad Ratib, "Ad-Dars: 2 -Surat at-Takwir-Tafsir al-Ayat 15-29, al-Insan Makhluq Mukarram Mukallaf". http://www.nabulsi.com/web/

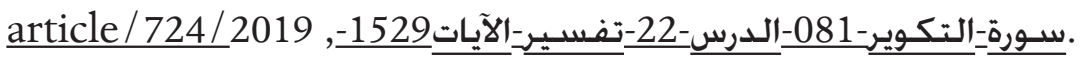

Al-Najjār, Mājid, Min Malāmih ad-Dalālah as-Șawtiyyah fi al-Qur'ān al-Karīm. Majallah Ahl al-Bait no. 4: 222-249. http://abu.edu.iq/research/journals/ ahl-al-bayt/issues/4, 2006.Qabha, Mahdi 'Inād Ahmad, At-Tahlīl al-Ṣawți li alNaș,. Tesis. Palestina: Jami’ah al-Najah al-Watniyah, 2011.

Qabhā, Mahdi ‘Inād Ahmad, At-Tahlīl al-Ṣawți li al-Naș, Tesis. Palestina: Jami’ah alNajah al-Watniyah, 2011.

Al-Qațtan, Mannā', Mabāhis fi Ulūm al-Qur'ān, Cairo: Maktabah Wahbah.

Al-Rafi'i, Mustafa Sadiq, I’jaz al-Qur'an wa al-Balagah an-Nabawiyyah, Beirut: Dar al-Kutub al-Arabi, Cet. IX, 1973.

Ramdlan, Dadan Ahmad, "Makhroj dan Sifat-Sifat Huruf Hijaiyyah dalam alQur'an, http:// dadanar.blogspot.com/2013/11/makhroj-dan-sifat-sifathuruf-hijaiyyah.html.

Wadelkebeida, Abd al-Rahmān Muhammad, "Musiqī al-Kalimāt wa Kalimāt alMusiqī fi al-Lugah al-Arabiyyah",http://www.wadelkebeida.net/index.php/ en/art/250-mseqakalemat.

https:/ / ar.wikipedia.org/wiki/ بيد_بن_ربيعة

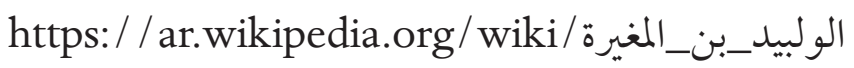

